\title{
Die Perikope in Johannes 8:21-30
}

\section{H du Plessis}

Geen wetenskaplike ondersoek behoort sonder 'n duidelike omlynde doel voor oë gedoen te word nie. So is daar ook hier 'n bepaalde doel wat nagestreef word. Die doel het te doen met die praktiese toepassing van eksegetiese resultate. 'n Eksegetiese resultaat moet die betekenis van ' $n$ bepaalde teksgedeelte na vore bring. Hierdie betekenis word deur die predikant in 'n preek gebruik om 'n bepaalde dogma te fundeer. Die doel van hierdie ondersoek word soos volg omskryf: Die sinvolheid van perikoop-vasstelling vir die verkryging van betekenis na aanleiding van Johannes 8:1-30.

In die Griekse teks van die United Bible Societies (derde druk) is die genoemde teks as 'n eenheid gedruk onder die opskrif, "Where I am Going You Cannot Come". In die Afrikaanse vertaling van 1979 verskyn die gedeelte ook as ' $n$ eenheid maar onder ' $n$ ander opskrif, naamlik "Die Jode ken Jesus nie". Hieruit is dit duidelik dat daar nie eensgesindheid bestaan oor wat die betekenis van die teksgedeelte, aangedui deur Johannes 8:1-30 moet wees nie.

Wanneer daar vraagtekens oor die betekenis van 'n teks is, kan die saak alleen opgelos word deur die oppervlakte- en dieptestrukture in oënskou te neem. Die enigste uitweg om dit behoorlik te doen, is om 'n kommata - en kolon-indeling van die Griekse teks en daarna ' $n$ struktuur ontleding te doen.

Die kolon-indeling met die kommata-struktuur verbindings is soos volg:

1. (a)

r oun palin autois

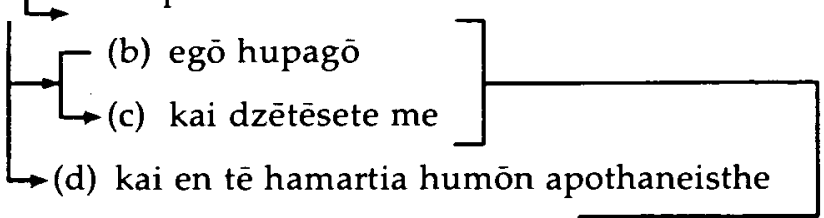

(e) hopou egō hupagō

$\longrightarrow$ (f) humeis ou dunasthei elthein

Die opmerklike van hierdie kolon lê in komma (d). Die komma hang as 't ware in die lug. Kommata (e) en ( $f$ ) is direkte uitbreidings van (b) en (c). 'n Mens kom noodwendig hier tot die konklusie dat die inhoud van hierdie kolon gebou is rondom die gedagte wat in komma (d) na vore kom. Dit is dus 'n ring-komposisie in die kleine. 
2. (a) elegon oun hoi Joudaioi

$\longrightarrow$ (b) mēti apoktenei heauton

$\longrightarrow$ (c) hoti legei

$\longrightarrow$ (d) hopou egō hupagō

$\rightarrow$ (e) humeis ou dunasthe elthein

3. (a) kai elegen autois

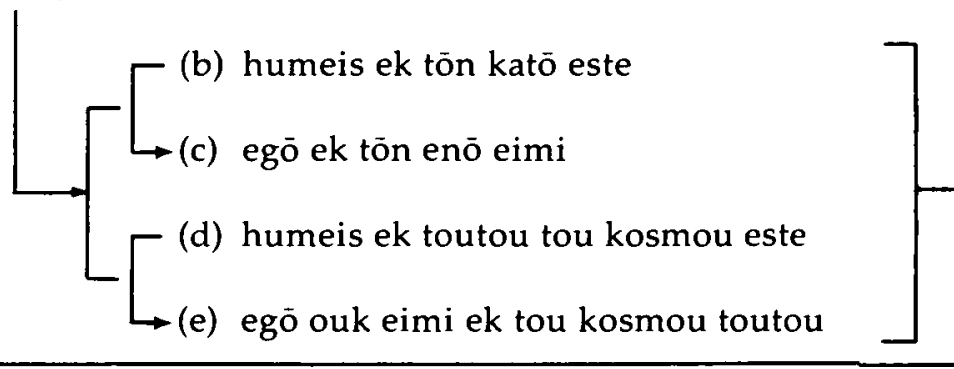

(f) eipon oun humin hoti apothaneisthe en tais hamartiais humōn

(g) ean gar mè pisteuète hoti egō eimi

(h) apothaneisthe en tais hamartiais humōn

Dit wat in 1(d) die kop begin uitsteek het, het hier in kolon 3 uitgekristalliseer. Hierdie kolon is 'n duidelike uitbreiding van kolon 1 en dan veral komma (d) van daardie kolon soos dit duidelik hier in kommata (f), (g) en (h) na vore kom. Tot hiertoe lyk dit of dit in hierdie teksgedeelte gaan om dit wat deur die groepering "apothaneisthe en tais hamartiais humōn" na vore gebring word, en dit wat daarmee saamgaan.

4. (a) elegon oun autō

$\longrightarrow$ (b) su tis ei;

Hierdie vraag word gevra na aanleiding van die "egō eimi" in 3(g) en dit is moontlik dat hiermee 'n nuwe gedagte in hierdie teksgedeelte na vore gebring wil word. Hierdie moontlikheid sal slegs vasgestel of afgewys kan word uit wat direk hierop volg. Wanneer dit wel so is dat hierdie kolon die begin van 'n nuwe gedagteeenheid is, is daar in hierdie teksgedeelte meer as een gedagteeenheid aanwesig. Hier sal dan 'n verdeling van perikope gedoen moet word wanneer daar gevra word na die betekenis van hierdie bepaalde teksgedeelte. Lê die oorsaak van betekenisverskille, soos opgemerk, in 'n verdeling wat hier moet plaasvind maar nie gedoen is nie? 
5. (a) eipen autois ho Jèsous
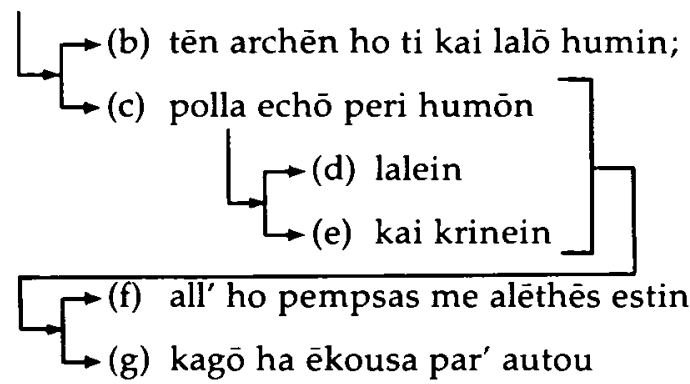

$\longrightarrow$ (h) tauta lalō eis ton kosmon

Hierdie kolon beantwoord nie die vraag in kolon 4 direk nie, maar tog word daar 'n indirekte antwoord gegee. Die antwoord word gegee deur die rede vir die "egō eimi" te gee. Die rede kom in die klimaks van kolon 5, naamlik kommata ( $f$ ), (g) en (h) na vore. Reeds hier moet die aandag daarop gevestig word dat die gedagte vervat deur die groepering "apothaneisthe en tais hamartiai humōn" nie meer teenwoordig is nie. Dit gaan nou oor ' $n$ konsep wat in die verbygaan daarmee saam genoem is: die "egö eimi" konsep.

6. (a) ouk egnōsan hoti

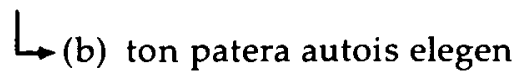

Hierdie kolon is duidelik 'n tussenwerpsel. Dit is nie deel van die gesprek wat tot hiertoe gevoer is nie. Dit wil slegs as verheldering dien sodat die gesprek verstaan kan word.

7. (a) eipen oun (autois) ho Jēsous

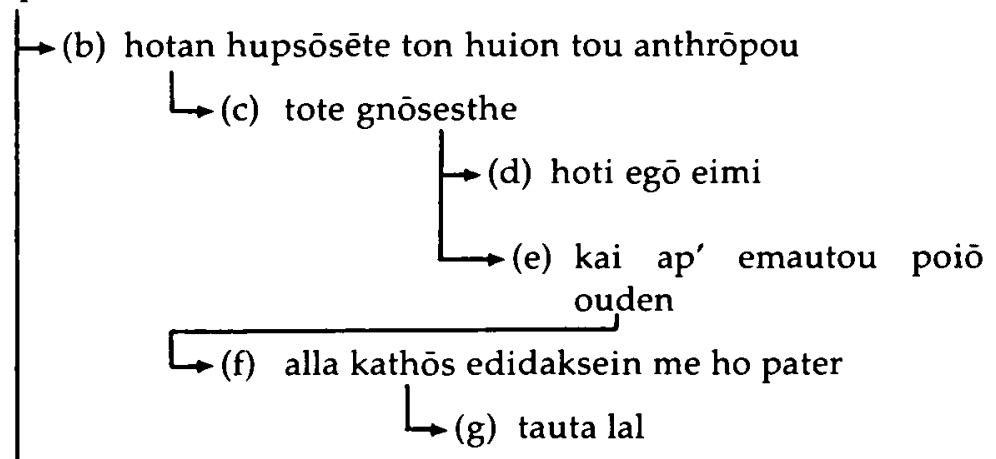

(h) kai ho pempsas me

$\left[\begin{array}{l}\text { (i) met' emou estin } \\ \text { (j) ouk aphēken me monon }\end{array}\right]$

$\longrightarrow$ (k) hoti egō ta aresta autō poiō pantote 
Kolon 5 word hier uitgebrei. Na die verheldering in kolon 6 word hier voortgegaan met die indirekte antwoord op die vraag wat in kolon 4 gevra is. Die finaliteit van die "egō eimi" en die konsekwensies daarvan word hier gegee. Dit word gedoen in kommata (b) tot (g). So word ook die waarheid daarvan bevestig in kommata (h) tot (k).

8. (a) tauta autou lalountos

$\zeta$ (b) polloi episteusan eis auton

Onmiddellik kom hier 'n nuwe gedagte na vore. Dit gaan hier glad nie om die "apothaneisthe en tais hamartiai humōn" of om die "egō eimi" nie, maar dit gaan om die reaksie op beide hierdie twee aspekte wat plaasgevind het.

Uit wat voorafgaan, is dit duidelik dat ons in hierdie teksgedeelte te doen het met drie duidelik omlynde gedagtes. Dit word dan die drie gedagtes wat in drie betekeniseenhede saamgesnoer is, waarin elke eenheid ook sy newekomponente het soos dit duidelik in die strukture van die onderskeie kola na vore kom. Hierdie drie betekeniseenhede vorm, wat genoem word, drie verskillende perikope.

Uit die stukturering van die onderskeie kola met mekaar sal die grense van die verskillende perikope saam met die kolonverbindings aangedui word. ' $n$ Bespreking van die strukturering sal ook gedoen word. Hiermee saam sal 'n opsommende parafraserende verduideliking ook gegee word.

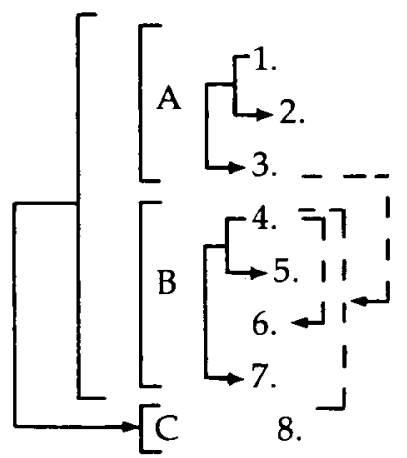

Ter verduideliking net eers die volgende: Die letters A, B, en C dui die verskillende perikope aan. Die syfers dui die onderskeie kola aan. Die gebroke lyne dui 'n indirekte of oorsaaksverbinding aan. Die ononderbroke lyne dui weer 'n direkte afhanklikheid aan. Dit geld ook vir die verbindingslyne tussen die onderskeie perikope.

Perikoop A: Dit gaan hier om die gedagte dat die Jode vanweë hulle sondes sal sterwe. Daarom sal hulle Jesus nie kan volg waarheen Hy 
op pad is nie - dit is na die koninkryk van die hemele. Die uitweg is dat hulle Jesus as die waarheid sal aanvaar en in Hom sal glo. Dan is die logiese konsekwensie dat hulle Jesus wel na die hemel sal kan volg.

Perikoop B: Hier gaan dit daarom dat die Jode nie wou insien dat Jesus die seun van God die Vader is nie. Jesus is ook al moedeloos om dit oor en oor te verduidelik, tog sal Hy aanhou om dit te doen omdat Hy die wil van sy Vader doen. Die Jode, diegene wat hulle nie wou bekeer nie, sal met die weerkoms van Jesus sien dat Hy werklik die waarheid gepraat het - $\mathrm{Hy}$ is wat Hy sê Hy is. Die konsekwensie wat hieruit getrek word, is dat die wat nie wil anvaar dat Jesus is wat Hy sê Hy is nie, maar kan wag; hulle sal net teleurgesteld wees omdat hulle gewag het.

Perikoop C: Die ander reaksie op wat Jesus oor Homself te sê gehad het, kom hier na vore. Dit is die aanvaarding daarvan dat $\mathrm{Hy}$ is wat Hy sê $\mathrm{Hy}$ is. Sommige van die Jode wat tot geloof gekom het, sal Jesus dus kan volg. Dit gaan hier om die pad wat Jesus deur die dood heen vir die mens sal voorberei. Hulle het nie nodig om te wag vir die oordeelsdag om Jesus te ken nie, en die gevolge van die wag te ervaar nie; hulle ken Hom reeds.

Daar is dus in die teksgedeelte Johannes 8:21-80 drie selfstandige betekeniseenhede ingebed. Alhoewel daar in die dieptestruktuur onderlinge verbindings tussen die drie perikope bestaan, soos byvoorbeeld die "egō eimi" -gedagte is dit geen genoegsame bewys om hierdie teksgedeelte as 'n gedagte-eenheid te klassifiseer nie. Dit is egter moontlik om 'n enkele opskrif vir hierdie teksgedeelte te gee, maar dan moet dit in die opskrif gaan om die gedagte in Perikoop C, omdat die ander twee perikope daarin weerspieël word.

'n Laaste opmerking: Dit is noodsaaklik dat 'n bepaalde teks nie op gesigswaarde geskat sal word nie, maar dat die onderlinge samehang daarvan ook in ag geneem sal word. Want dan alleen sal die werklike betekenisaspek(te) na vore gebring kan word. So kan deeglik gefundeerde prediking na vore gebring word. Hierin kan struktuurontleding 'n belangrike rol speel. Die verskillende gedagte-eenhede kan dan na betekenis uitgelig word om sodoende die selfstandigheid van elke perikoop raak te sien. 